\title{
Investigation of Mechanical Properties of Basalt Particle-Filled SMC Composites
}

\author{
Kadir Cavdar ${ }^{1}$ and Mahmut Bingol ${ }^{2,3}$ \\ ${ }^{1}$ Mechanical Engineering Department, Uludağ University, Gorukle, 16059 Bursa, Turkey \\ ${ }^{2}$ Mechanical Engineering Department, Institute of Science, Uludağ University, Gorukle, 16059 Bursa, Turkey \\ ${ }^{3}$ Vocational School of Yalova, Yalova University, 77100 Yalova, Turkey \\ Correspondence should be addressed to Kadir Cavdar; cavdar@uludag.edu.tr
}

Received 9 June 2016; Revised 5 August 2016; Accepted 18 August 2016

Academic Editor: Jun Deng

Copyright (C) 2016 K. Cavdar and M. Bingol. This is an open access article distributed under the Creative Commons Attribution License, which permits unrestricted use, distribution, and reproduction in any medium, provided the original work is properly cited.

Basalt particles have been investigated as a novel additive for the production of glass fibre reinforced composite using sheet moulding compound (SMC) method. Compared to the $\mathrm{CaCO}_{3}$ that are widely used as filler in the SMC composite, the resulting composites exhibit improved mechanical properties. The tensile strength increased by approximately $15 \%$, whereas the flexural strength was enhanced by $8 \%$ in SMC composites prepared by basalt particles. Examination of the surface morphology and interfacial debonding of the specimens is also performed via scanning electron microscopy. Superior strength properties are observed in the basalt particle-reinforced composites compared to those with the $\mathrm{CaCO}_{3}$ fillers.

\section{Introduction}

Polymer composites are composed of an inorganic reinforcement and a polymeric matrix, providing the desired combination of mechanical, chemical, and thermal resistance features. Due to its distinct advantages such as design flexibility, dimensional stability, consolidation of parts, high strength, light weight, moderate tooling and finishing costs, and corrosion resistance, sheet moulding compound (SMC) is one of the widely used composite preparation methods. The SMC method is a sheet of ready-to-mould composites containing uncured thermosetting resins and uniformly distributed short fibres and fillers. Commonly, glass fibre is used as a reinforcement material and unsaturated polyester as a matrix, along with various fillers and additives in the prepreg formulation. Calcium carbonate $\left(\mathrm{CaCO}_{3}\right)$ is cheap and easily available filler and thus is the most widely used filler in the composite preparation. Due to its high surface energy, the $\mathrm{CaCO}_{3}$ reduces mechanical properties of the composite materials [1].

Basalt is a rigid, hard, and durable volcanic mineral which is dark grey or black in colour. It consists of approximately $50 \% \mathrm{SiO}_{2}$ basalt and originated from the solidification of hot magma flows rising from volcanoes or cracks in the earth's crust. Recently, basalt fibre is used as an alternative reinforcement material, which exhibits exceptional characteristics and mechanical properties compared to those of glass fibres. Basalt-polymer materials are primarily used in building construction, and then they began to be employed in the automobile, machine, and aerospace industries as a replacement for traditional glass and carbon fibre reinforcements [2-5]. Moreover the basalt fibre is fire resistant and forms insulation against sound and heat and thus presents a more economical alternative to the carbon fibre. For instance, the chopped basalt fibre can also be mixed with cement to provide both lower weight and higher structural strength [6-8]. Similarly, basalt particles have also been used as fillers for polymer composites. An important feature of the basalt particle is its suitability for the moulding process. By adding basalt particles at a specific rate into the polymer matrix the corresponding composites were produced via moulding. The various properties of these materials involving wear, mechanical properties, and chemical resistance are remarkably enhanced and no bubbles or pores were observed in the structure $[9,10]$.

A novel strategy has been developed to improve the fibre reinforced composite properties by introduction of additional particles in the polymer matrix. For example, the 
TABLE 1: Chemical compositions of basalt particle [12].

\begin{tabular}{lc}
\hline Compound & Weight percentage in basalt (\%) \\
\hline $\mathrm{SiO}_{2}$ & $51.6-57.5$ \\
$\mathrm{Al}_{2} \mathrm{O}_{3}$ & $16.9-18.2$ \\
$\mathrm{CaO}$ & $5.2-7.8$ \\
$\mathrm{MgO}$ & $1.3-3.7$ \\
$\mathrm{Na}_{2} \mathrm{O}$ & $2.5-6.4$ \\
$\mathrm{~K}_{2} \mathrm{O}$ & $0.8-4.5$ \\
$\mathrm{Fe}_{2} \mathrm{O}_{3}$ & $4.0-9.5$ \\
\hline
\end{tabular}

mechanical properties of carbon fibre reinforced epoxy composites have been enhanced by the addition of graphene nanoparticles, which enhance the interface mechanics via chemical bonding [11]. In another study, Ary Subagia et al. examined the effect of different tourmaline micro/nanoparticle fillers in basalt fibre reinforced epoxy composites produced via vacuum-assisted resin transfer moulding. With the addition of the particles, the composites gained increased tensile and flexural properties [2].

In this study, a comparative study for the SMC composites prepared with glass fibre reinforced composite containing either $\mathrm{CaCO}_{3}$ or basalt particles has been reported based on their microstructure and mechanical properties. The composites produced from basalt particles had better mechanical properties compared with $\mathrm{CaCO}_{3}$ particle-reinforced SMC composites. The mechanical properties of the specimens are investigated in accordance with the standard tests. The surface morphology of the specimens is examined in more detail via scanning electron microscopy.

\section{Materials and Methods}

2.1. Materials. The basalt particle is purchased from Basaltex (Masureel Group, Belgium) and its chemical composition is given in Table 1.

The E-glass fibre with bundle diameters of $15 \mu \mathrm{m}$ is provided by Cam Elyaf A.S. (SMC3-2400) and cut into $65 \mathrm{~mm}$ length and added into resin randomly at a concentration of $20 \%$ by weight. For the unsaturated polyester resin, Polipol ${ }^{\mathrm{TM}}$ 347-BMC-SMC (Poliya, Istanbul, Turkey) is used in the experiments, and the resin properties are given in Table 2.

2.2. Preparation of SMC Composites. The SMC composites are produced in two steps. In the first step, the prepreg formulation is prepared according to a given formulation (Table 3) and is incubated for a maturation period (Figure 1). This time period plays a vital role in the bonding between the resin and the fibre. Hence, this bonding also affects the mechanical properties of the composite material.

In the second step, the SMC plates were retained in a specially prepared $140 \times 280 \mathrm{~mm}^{2}$ sheet mould at temperatures of $140-150^{\circ} \mathrm{C}$ under the effect of 80 -bar constant pressure for about 4 min (Figure 2).

2.3. Characterization. A diamond saw is used to cut the manufactured plates and the specimens are prepared according to ISO527 and ISO178, respectively, for tensile and
TABLE 2: Polyester resin properties.

\begin{tabular}{lc}
\hline Property & Value \\
\hline Density & $1.118 \mathrm{gr} / \mathrm{cm}^{3}$ \\
Tensile strength & $52 \mathrm{MPa}$ \\
Flexural strength & $117 \mathrm{MPa}$ \\
Elongation at break & $3.86 \%$ \\
\hline
\end{tabular}

TABLE 3: The formulation of SMC prepreg.

\begin{tabular}{lc}
\hline Compound & Weight percentage (\%) \\
\hline Unsaturated polyester & 36 \\
Thermoplastic resin & 10 \\
Polymerization catalyst & 0.5 \\
CaCO $_{3}$ or basalt particle & 30 \\
Glass fibre SMC3-2400 $(65 \mathrm{~mm})$ & 20 \\
Other additives & 3.5 \\
\hline Total & 100 \\
\hline
\end{tabular}

flexural strength tests. The tensile tests are performed with the Shimadzu-AG-I machine at a speed of $5 \mathrm{~mm} / \mathrm{min}$ and the flexural tests are done using the Zwick-1446 machine (Figure 3) at $2 \mathrm{~mm} / \mathrm{min}$.

The morphological features of the broken composite surfaces obtained from the tensile and flexural tests are characterized by SEM (Carl Zeiss EVO 40) with accelerating voltage of $20 \mathrm{kV}$. The specimen surfaces are coated with gold palladium and observed under reduced pressure.

\section{Results and Discussion}

The strength of the composite materials is directly related to the interfacial mechanics between matrix and fibre. The interface strength increases the composite material strength. In recent years, some attempts have been made to improve these chemical and mechanical bonds. The particle additives are usually aimed at reducing the cost, but the chemical and physical properties of composite materials featuring particles produced with additives are also improved. Basalt fillers are used in road construction and, in mineral form, for heat and sound insulation. As a reinforcing filler material, it is used in composites where improved mechanical properties are desired. Moreover, it is also used to improve wear and corrosion resistance. In this study, the specimens were produced with basalt particles instead of the commonly used $\mathrm{CaCO}_{3}$ filler and the mechanical properties of these new composite materials were investigated. The specimens were broken using testing equipment according to standard procedures, as shown in Figure 4.

Generally, glass fibre provides the greatest strength when used as the reinforcement material in SMC composites, whereas the $\mathrm{CaCO}_{3}$ fillers are useful to tune the paste viscosity and reduce the cost. The main purpose of this study is to improve the mechanical properties of SMC composites through the improvement of matrix properties by the addition of basalt particles instead of $\mathrm{CaCO}_{3}$ fillers. The replacement of $\mathrm{CaCO}_{3}$ fillers with basalt particles brings 


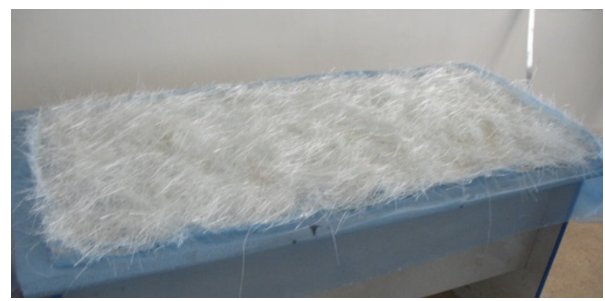

(a)

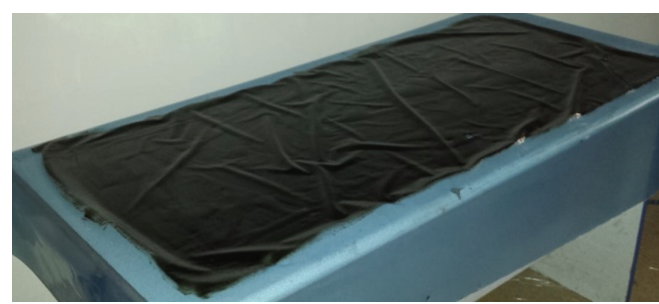

(b)

FIgURe 1: Prepreg formulations containing (a) $\mathrm{CaCO}_{3}$ and (b) basalt particles.

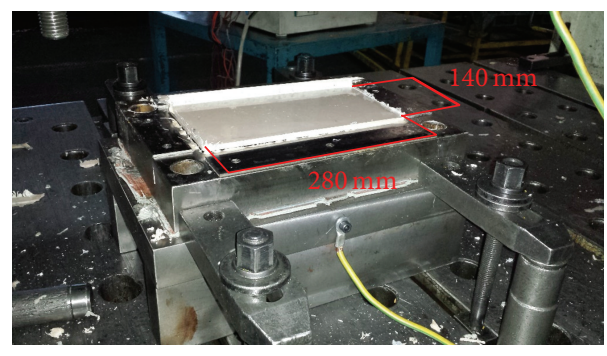

(a)

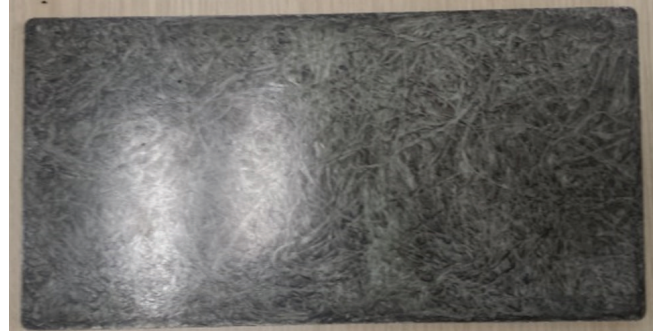

(b)

Figure 2: (a) SMC plate containing $\mathrm{CaCO}_{3}$ filler in the mould and (b) SMC plate containing basalt filler.

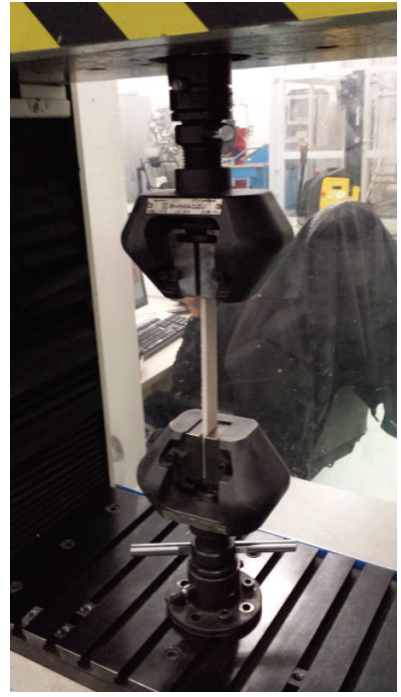

(a)

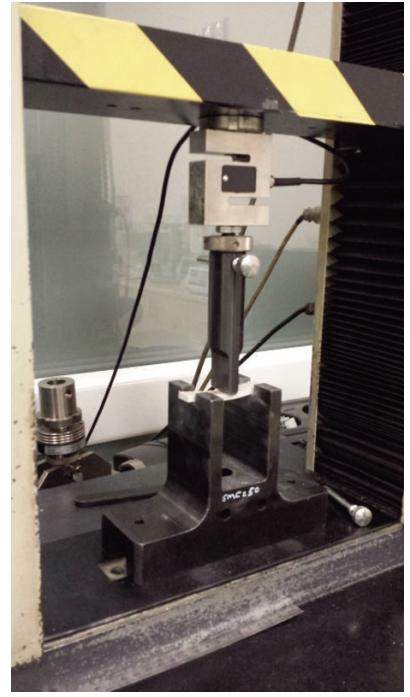

(b)

Figure 3: The specimens fixed the testing device (a) tensile and (b) flexural tests.

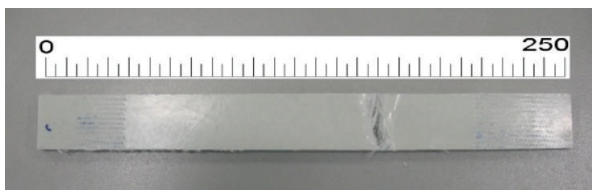

(a)

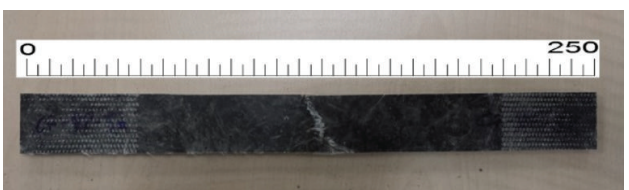

(b)

FIgURE 4: Broken test specimens, (a) filled with $\mathrm{CaCO}_{3}$ and (b) filled with basalt particles. 


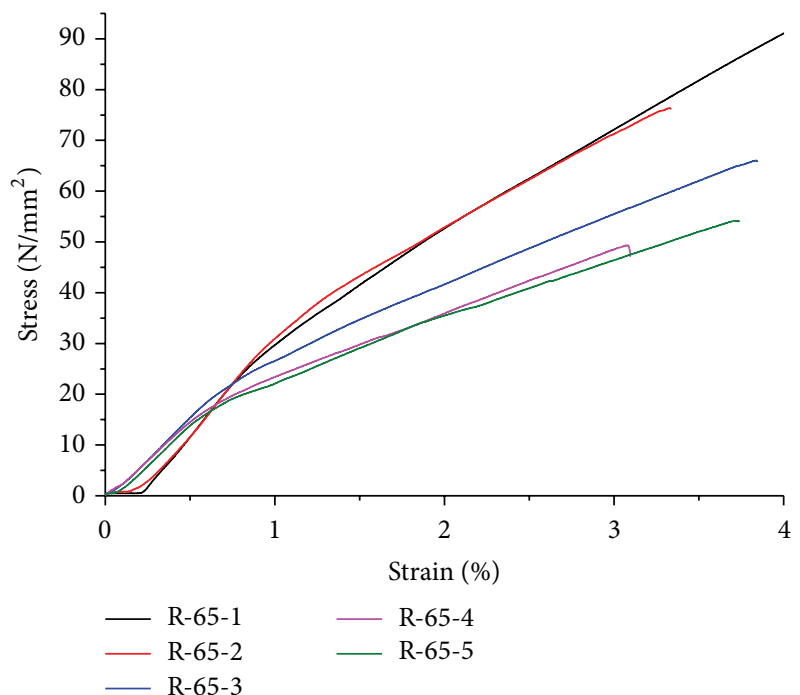

(a)

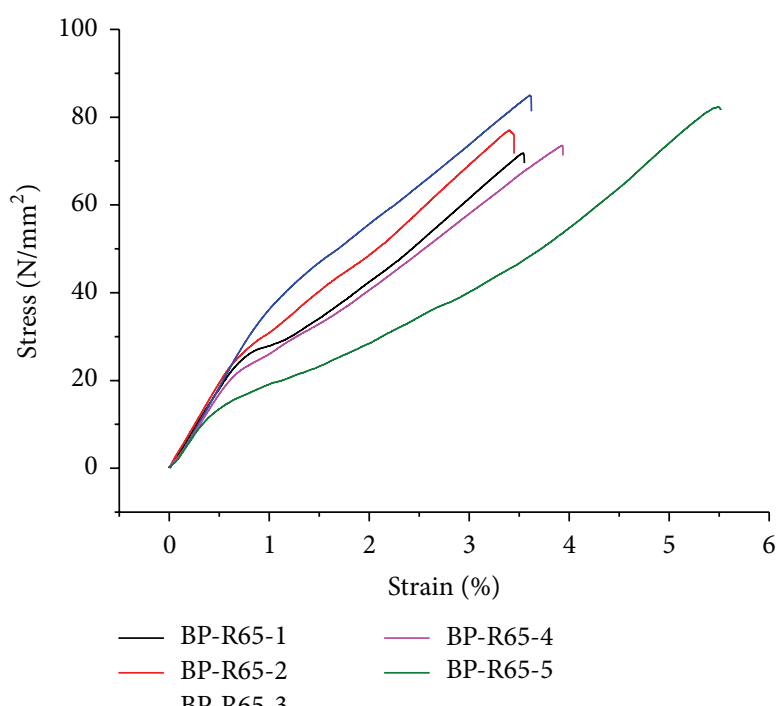

(b)

FIGURE 5: Tensile strength values of composite materials filled with $\mathrm{CaCO}_{3}$ (a) and basalt particles (b).

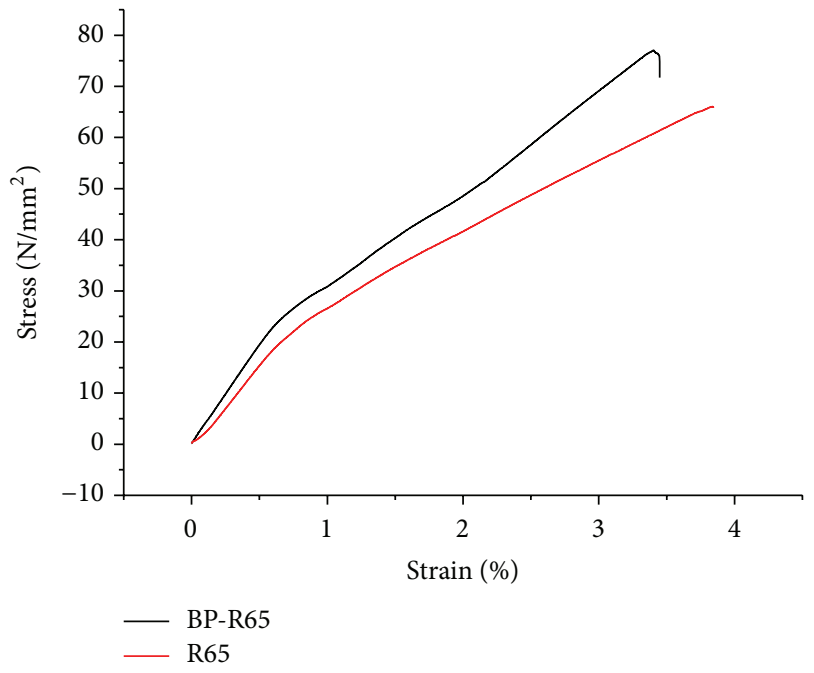

FIgURE 6: Sample tensile strength values of a specimen.

many outstanding features such as being fire resistant, explosion-proof, and nontoxic and not reacting with the air or water in the matrix. Both tensile and flexural tests confirmed that the SMC composite prepared by basalt fillers has better mechanical properties compared to the composite containing $\mathrm{CaCO}_{3}$ fillers. Without changing the reinforcement material (glass fibre), this increase in the mechanical properties by simple matrix modification is a significant finding. The tensile and flexural test results can be found in Figures 5 and 6. The tensile strength increased by approximately $15 \%$, whereas the flexural strength was enhanced by $8 \%$ (Figure 7).

In the literature, the failure mechanism of composite materials is usually explained in three stages. In the first stage, microcracks are formed in the matrix, followed by fibrematrix debonding and interfacial decohesion and eventually

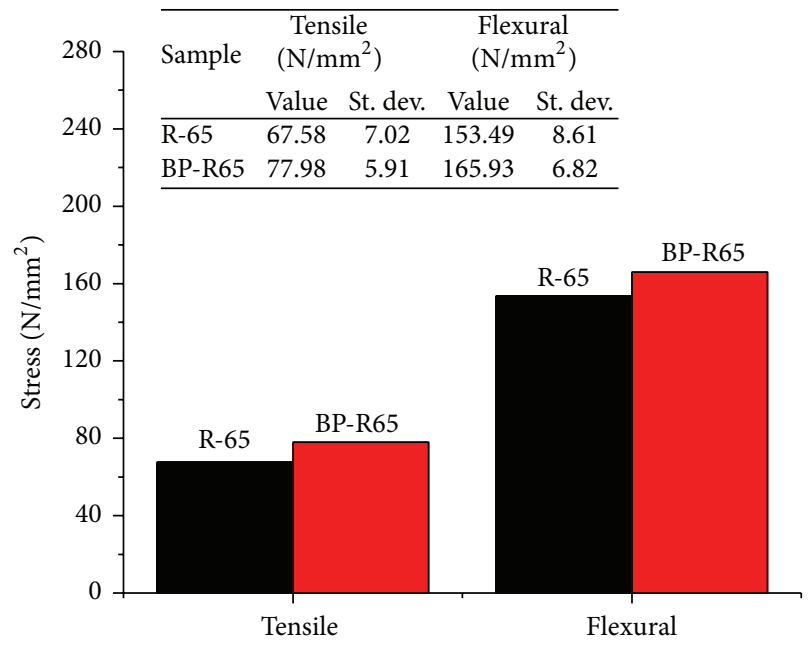

Figure 7: The average values for tensile and flexural strength values of R-65 and BP-R65 test specimens.

by fibre breakage [13-17]. In our case, the basalt particles not only prevent the microcracks of the final composites but also improve the cohesion between glass fibre and matrix; thus the mechanical properties of SMC composites are significantly enhanced. The average tensile and flexural strength values obtained with samples using $\mathrm{CaCO}_{3}$ and basalt fillers are given in Figure 7. This graphic shows that an increment trend in both tensile and flexural stress is obtained.

The morphology of SMC composites is also investigated by SEM equipment using fracture surfaces of the tensile and flexural specimens. In the $\mathrm{CaCO}_{3}$ filled SMC composite, it can be observed enveloping the fibre surface in Figure 8 and reducing the interfacial strength between the fibre and matrix. Due to insufficient interface strength, the pull-out of 

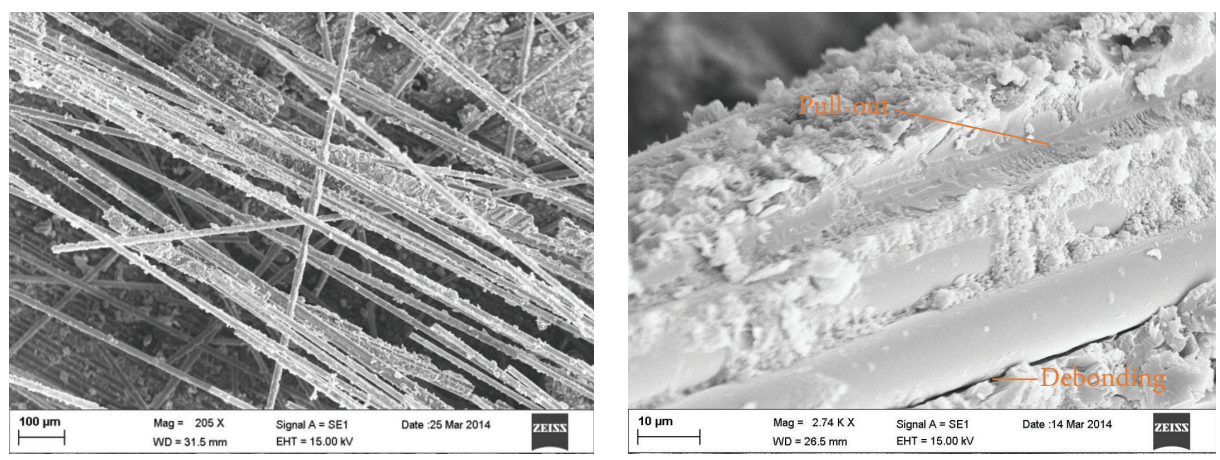

FIGURE 8: The SEM images of the SMC composite filled with $\mathrm{CaCO}_{3}$.
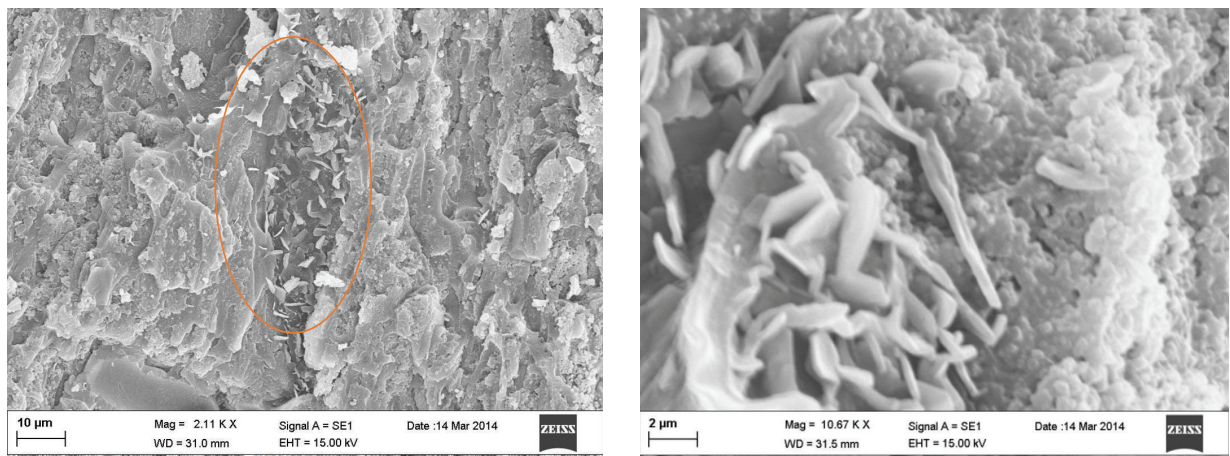

FIGURE 9: The SEM images of SMC composite filled with basalt particles.

glass fibre easily occurred in the matrix. Consequently, the interfacial debonding results in a decrease in both tensile and flexural strengths.

On the other hand, in the case of basalt particlereinforced composite, the basalt particles help to hold the glass fibre together with matrix in the composite (Figure 9). Thus, the formation of microcracks in the matrix particles has been relatively delayed in the first stage of damage. Hence, the mechanical properties of the SMC plates are remarkably improved and the failure mechanism has been deferred.

\section{Conclusions}

In conclusion, basalt particles as an alternative filler for glass fibre reinforced SMC composite has been investigated. Compared to the $\mathrm{CaCO}_{3}$ fillers that are generally used in the SMC composite, the basalt particles filled sample exhibits significant improvement on the tensile and flexural strengths. The morphologies of the obtained SMC materials are investigated by SEM analysis. In the $\mathrm{CaCO}_{3}$ filled composites, fibre pull-out and interfacial debonding more easily occurred due to the high surface energy. This could be responsible for reducing the mechanical properties of the nonpolar matrices. Conversely, the basalt particles hold glass fibre and matrix together and resulted in improved strength properties. In the future studies, the proportion of basalt fillers and new SMC production methods will be examined in order to achieve better mechanical properties.

\section{Competing Interests}

The authors declare that there is no conflict of interests regarding the publication of this paper.

\section{Acknowledgments}

This paper is based upon work supported by Uludağ University (Research Grant no. UAP(M) 2011-29). The authors are grateful to Dr. Mehmet Atilla Tasdelen from Yalova University Polymer Engineering Department for his valuable contributions.

\section{References}

[1] V. M. Tuan, D. W. Jeong, H. J. Yoon et al., "Using rutile $\mathrm{TiO}_{2}$ nanoparticles reinforcing high density polyethylene resin," International Journal of Polymer Science, vol. 2014, Article ID 758351, 7 pages, 2014.

[2] I. D. G. Ary Subagia, L. D. Tijing, Y. Kim, C. S. Kim, F. P. Vista IV, and H. K. Shon, "Mechanical performance of multiscale basalt fiber-epoxy laminates containing tourmaline micro/nano particles," Composites Part B: Engineering, vol. 58, pp. 611-617, 2014.

[3] V. Lopresto, C. Leone, and I. De Iorio, "Mechanical characterisation of basalt fibre reinforced plastic," Composites Part B: Engineering, vol. 42, no. 4, pp. 717-723, 2011.

[4] I. D. G. Ary Subagia, Y. Kim, L. D. Tijing, C. S. Kim, and H. K. Shon, "Effect of stacking sequence on the flexural properties 
of hybrid composites reinforced with carbon and basalt fibers," Composites Part B: Engineering, vol. 58, pp. 251-258, 2014.

[5] D. Asprone, E. Cadoni, F. Iucolano, and A. Prota, "Analysis of the strain-rate behavior of a basalt fiber reinforced natural hydraulic mortar," Cement and Concrete Composites, vol. 53, pp. 52-58, 2014.

[6] C. Colombo, L. Vergani, and M. Burman, "Static and fatigue characterisation of new basalt fibre reinforced composites," Composite Structures, vol. 94, no. 3, pp. 1165-1174, 2012.

[7] K. Singha, "A short review on basalt fiber," International Journal of Textile Science, vol. 1, no. 4, pp. 19-28, 2012.

[8] B. Wei, H. Cao, and S. Song, "Surface modification and characterization of basalt fibers with hybrid sizings," Composites Part A: Applied Science and Manufacturing, vol. 42, no. 1, pp. 22-29, 2011.

[9] A. Akinci, H. S. Yetgin, S. Yllmaz, and U. Sen, "The variation of pin-on-disc wear properties of particle filled polymer matrix composites with applied loads," Journal of Engineering and Natural Sciences, vol. 27, pp. 129-138, 2009.

[10] A. Todic, B. Nedeljkovic, D. Cikara, and I. Ristovic, "Particulate basalt-polymer composites characteristics investigation," Materials \& Design, vol. 32, no. 3, pp. 1677-1683, 2011.

[11] V. Acar, H. Akbulut, M. Sarıkanat, O. M. Seydibeyoglu, Y. Seki, and S. Erden, "Karbon elyaf takviyeli prepreg kompozitlerde arayüzey mekaniğinin karbon nanoyapı katkısıyla iyileştirilmesi," Electronic Journal of Machine Technologies, vol. 10, no. 3, pp. 43-51, 2013.

[12] http://www.basaltex.com/files/cmsl/basalt-fibres-as-reinforcement-for-composites_ugent.pdf.

[13] J. Fitoussi, M. Bocquet, and F. Meraghni, "Effect of the matrix behavior on the damage of ethylene-propylene glass fiber reinforced composite subjected to high strain rate tension," Composites Part B: Engineering, vol. 45, no. 1, pp. 1181-1191, 2013.

[14] J. Fitoussi, F. Meraghni, Z. Jendli, G. Hug, and D. Baptiste, "Experimental methodology for high strain-rates tensile behaviour analysis of polymer matrix composites," Composites Science and Technology, vol. 65, no. 14, pp. 2174-2188, 2005.

[15] B.-Z. Huang and L.-J. Zhao, "Bridging and toughening of short fibers in SMC and parametric optimum," Composites Part B: Engineering, vol. 43, no. 8, pp. 3146-3152, 2012.

[16] R. O. Ochola, K. Marcus, G. N. Nurick, and T. Franz, "Mechanical behaviour of glass and carbon fibre reinforced composites at varying strain rates," Composite Structures, vol. 63, no. 3-4, pp. 455-467, 2004.

[17] K. Ogi and M. Yamanouchi, "Temperature dependence of flexural strength of a CF-SMC composite," Applied Composite Materials, vol. 18, no. 5, pp. 397-408, 2011. 

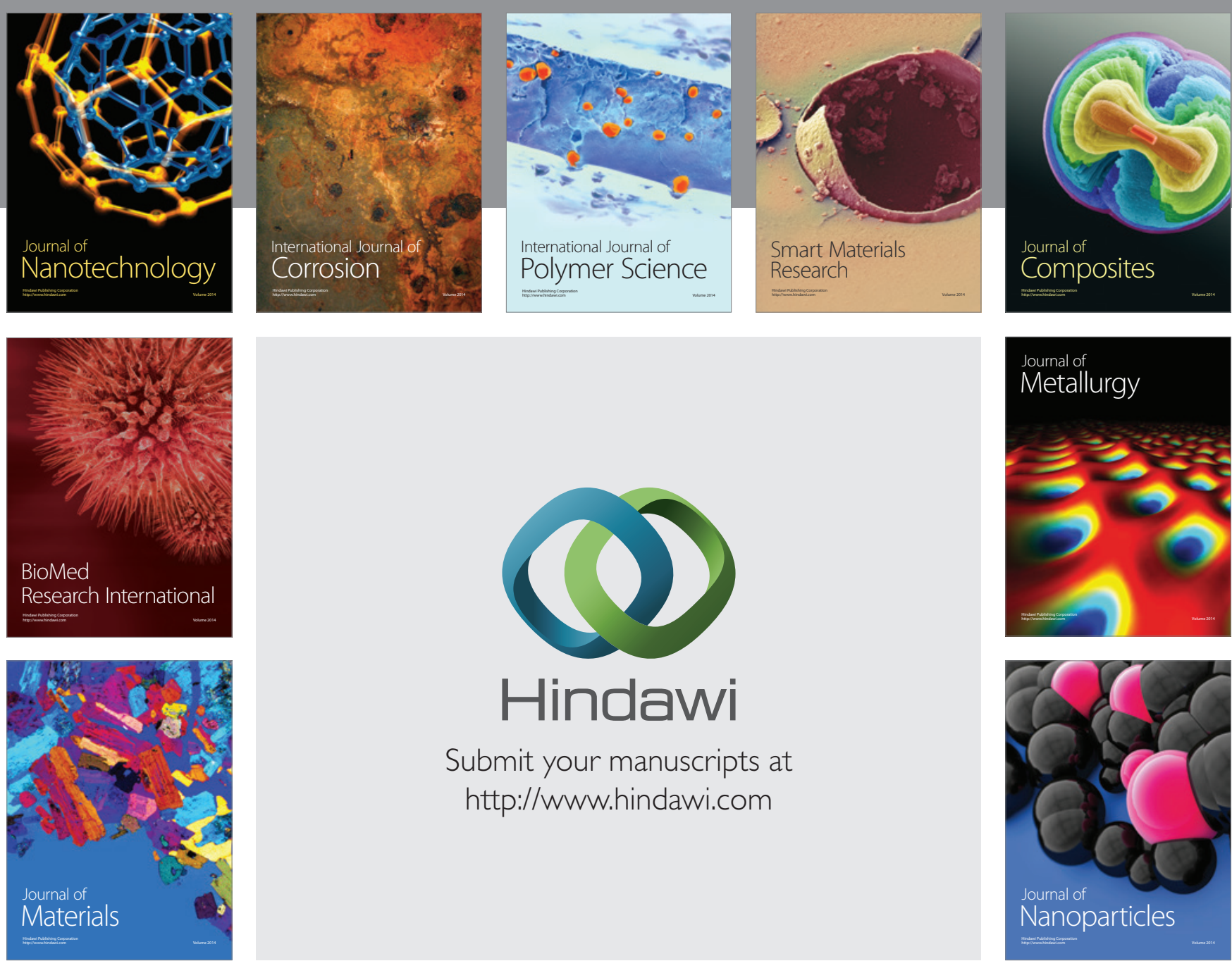

\section{Hindawi}

Submit your manuscripts at

http://www.hindawi.com

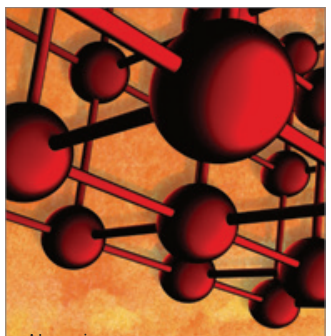

Materials Science and Engineering
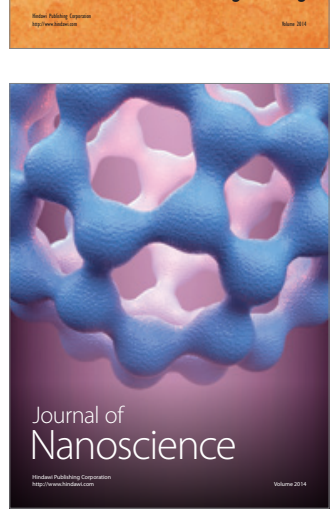
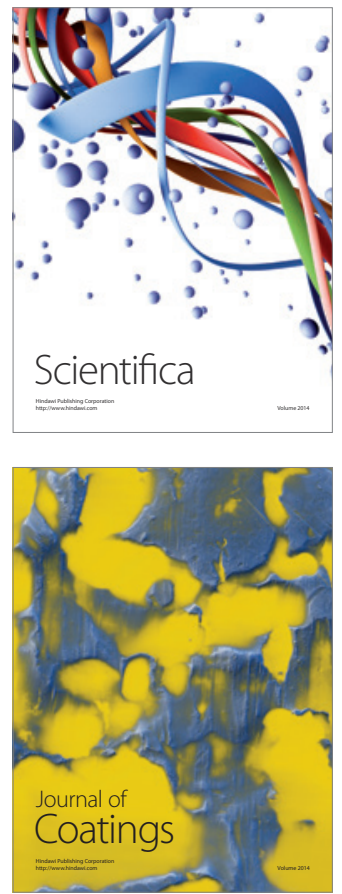
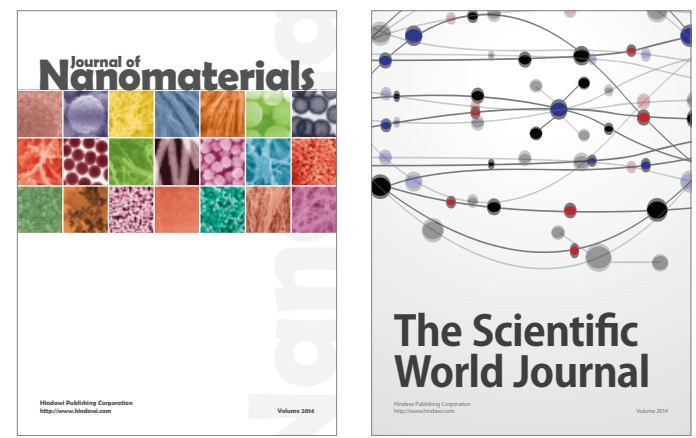

The Scientific World Journal
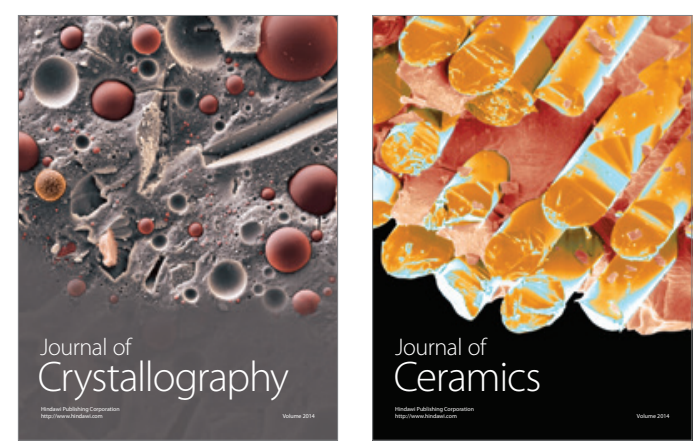
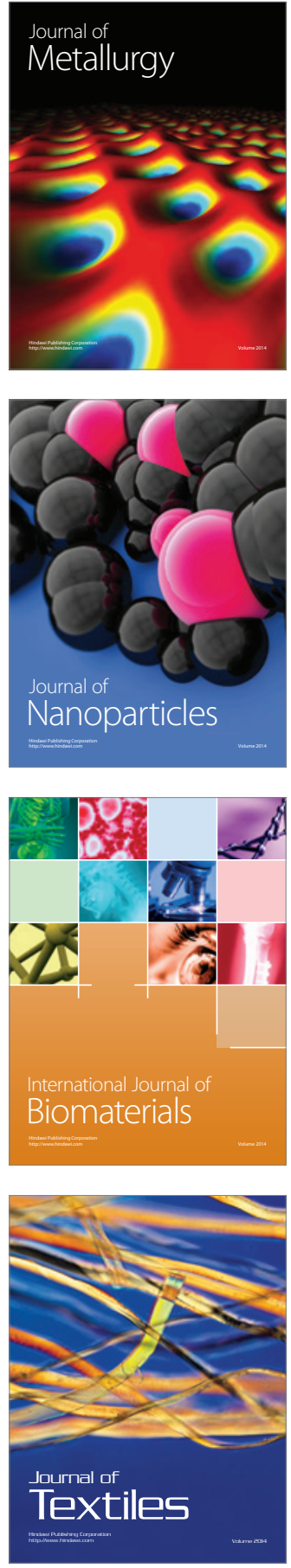